\title{
PELAKSANAAN KEGIATAN PRAMENYIMAK DAN PASCAMENYIMAK DALAM PRAKTIK MENYIMAK KULIAH MAHASISWA PBSI FBS UNY
}

\author{
Nurhidayah \\ Fakultas Bahasa dan Seni, Universitas Negeri Yogyakarta \\ Email: nurhidayahuny@yahoo.co.id
}

\begin{abstract}
ABSTRAK
Penelitian ini bertujuan untuk mendeskripsikan secara kualitatif pelaksanaan kegiatan pembelajaran keterampilan menyimak kuliah mahasiswa PBSI FBS UNY dengan pemaksimalan penerapan kegiatan pramenyimak (pre listening) dan pascamenyimak (post listening). Subjek penelitian ini adalah mahasiswa semester I program studi PBSI FBS UNY yaitu kelas A dan G. Tempat penelitian ini adalah seluruh wilayah FBS. Teknik pengumpulan data dalam penelitian ini adalah teknik observasi pertisipan (participant observer). Pengumpulan data dalam penelitian ini adalah peneliti sendiri sebagai instrumen inti dengan bantuan instrumen lain berupa catatan lapangan dan wawancara tidak terstruktur. Kredibilitas data dalam penelitian ini dicapai dengan trianggulasi. Analisis data penelitian ini menggunakan analisis deskriptif kualitatif. Hasil penelitian menunjukkan bahwa: Kegiatan pramenyimak (prelistening) yang dilakukan sebelum menyimak kuliah adalah: (1) diskusi, (2) membuat pertanyaan tentang topik (quest ion), dan (3) membaca sekilas (skimming) bacaan yang terkait dengan topik. Adapun kegiatan pascamenyimak (postlistening) yang dilakukan oleh mahasiswa adalah (1) menulis esai singkat (short written texts), (2) membuat ringkasan materi, (3) analisis kebahasaan (language work), (4) menggunakan kosakata tertentu yang baru dipahami untuk mengungkapkan gagasan (vocabulary work), (5) berdiskusi tentang materi yang sudah dipahami melalui kegiatan menyimak kuliah (group sharing), dan (6) membaca bacaan yang relefan dengan materi (reading). Pelaksanaan kegiatan pramenyimak (prelistening) dan (postlistening) baik berdasarkan kuantitas maupun kualitasnya belum maksimal. Pelaksanaan kegiatan pascamenyimak (postlistening) dapat terlaksana secara efektif jika dikemas dalam sebuah rangkaian tugas. Jika tidak demikian, pelaksanaan hanya dilakukan oleh mahasiswa tertentu yang berminat dan mahasiswa lain bertindak semaunya sendiri.
\end{abstract}

Kata Kunci: menyimak komprehensi, kegiatan pramenyimak (pre-listening), kegiatan pascamenyimak (post-listening)

\section{THE IMPLEMENTATION OF PRE-LISTENING AND POST-LISTENING ACTIVITIES IN THE PRACTICE OF LISTENING ATTENTIVELY TO LECTURES PERFORMED BY THE STUDENTS OF INDONESIAN LANGUAGE AND LITERATURE EDUCATION IN FBS UNY}

\begin{abstract}
This research aims at qualitatively describing the skill of listening attentively to lectures performed by the students of Indonesian Language and Literature Education Study Program of FBS by implementing pre-listening and post-listening activities optimally. The subjects of this research are the first-semester students of Indonesian Language and Literature Education Study Program from Class A and G. The research was conducted in Faculty of Languages and Arts. The data collecting technique was done by using the technique of participant observer, while the data collector was the researcher herself as the main instrument of this research by using other instruments such as field notes and interview. The data credibility was achieved through the triangulation method and the data analysis used qualitative descriptive analysis. The results show that the pre-listening activities conducted by the students are 1) having discussions, 2) delivering questions related to
\end{abstract}


the topics, and 3) skimming some related texts. Meanwhile, the post-listening activities conducted are 1) writing short essays, 2) making the summaries of the material, 3) doing language work, 4) doing vocabulary work, 5) having group sharing, and 6) reading some relevant texts. The implementation of pre-listening and post-listening was not quantitatively and qualitatively optimal. Post-listening activities can be conducted effectively if they are designed in the form of a variety of assignments. Otherwise, post-listening activities would only be conducted by students being interested in the lectures.

Keywords: comprehensively listening, pre-listening activities, post-listening activities

\section{PENDAHULUAN}

Pembelajaran keterampilan menyimak dalam kurikulum PBSI di UNY mencakup dua hal yaitu (1) pembelajaran keterampilan menyimak komprehensi dan kritis; dan (2) menyimak apresiatif dan kreatif. Perbedaan dari keduanya terletak pada tujuan masing-masing. Perbedaan tujuan ini berimplikasi pada penggunaan materi yang dijadikan sebagai sumber belajar dalam mata kuliah tersebut. Pembelajaran keterampilan menyimak komprehensi dan kritis mempunyai objek materi berupa berita, diskusi, seminar, khotbah, kuliah, dan iklan. Adapun objek materi dalam mata kuliah menyimak apresiatif dan kreatif yaitu berupa: puisi, lagu, cerpen, lawak, drama, dan juga film.

Kegiatan menyimak kuliah merupakan salah satu kegiatan dalam cakupan mata kuliah menyimak komprehensi dan kritis yang mempunyai peranan penting dalam proses pembelajaran di perguruan tinggi. Pemaksimalan kegiatan menyimak kuliah ini mempunyai banyak efek positif karena akan semakin memperkuat pemahaman seorang mahasiswa terhadap materi perkuliahan. Hal ini jelas karena dalam kegiatan pembelajaran yang merupakan sebuah bentuk komunikasi akademik, porsi terbesar yang dilakukan adalah kegiatan menyimak. Ini sejalan dengan pendapat Goh (2002:1) "Listening takes up as much as $50 \%$ ot our everyday communication time".

Aktivitas menyimak adalah suatu proses kegiatan mendengarkan lambang-lambang lisan dengan penuh perhatian, pemahaman, apresiasi, serta interpretasi, untuk memperoleh informasi, menangkap isi, serta memahami makna komunikasi yang disampaikan oleh si pembicara melalui ujaran atau bahasa lisan (Tarigan, 1985:19) Pengertian tersebut menyiratkan bahwa kegiatan menyimak tidak hanya sekedar mendengar atau mendengarkan informasi, tetapi juga mengolah informasi tersebut menjadi sebuah pemahaman yang dapat diaplikasikan dalam kehidupan sehari-hari. Dengan demikian, kegiatan menyimak khususnya menyimak kuliah merupakan kegiatan yang perlu mendapat perhatian.

Pada umumnya, budaya menyimak kuliah yang terjadi biasanya sebatas menyimak pasif keterangan dosen atau kegiatan presentasi yang dilakukan oleh teman sekelasnya. Sementara itu, tagihan proses perkuliahan biasanya lebih terfokus di hasil akhir. Padahal, sebuah proses akan banyak berpengaruh pada hasil secara keseluruhan. Berkaitan dengan proses dalam sebuah kegiatan pembelajaran, menyimak sebenarnya mempunyai serangkaian kegiatan yang dilakukan secara proporsional dan komprehensif dari sebelum sampai setelah menyimak. Oleh karena itu, idealnya kegiatan menyimak tidak hanya fokus pada saat pelaksanaan kegiatan praktik menyimak. Kegiatan tersebut sebaiknya merupakan rangkaian kegiatan berupa sebelum menyimak (pre listening), pada saat menyimak menyimak, dan pascamenyimak (post-listening).

Pembelajaran menyimak komprehensi dan kritis dapat didesain dalam bentuk kegiatan prelistening dan postlistening (Goh, 2002). Kegiatan pre-listening yang dapat dilakukan adalah brainstorming, mind mapping, diskusi, permainan, pertanyaan terbimbing, melengkapi ilustrasi dengan kata atau gambar sederhana, bertanya seputar topik, memprediksi isi, karakter, atau setting, mengeliminasi yang tidak sesuai dari gambar, kata atau frasa, membaca teks pendek, menulis paragraf pendek. Adapun kegiatan yang dapat dikategorikan dalam kegiatan post-listening yaitu menulis teks pendek, membuat ringkasan, presentasi, dramatisasi, bermain peran, analisis bahasa, kerja bahasa, 
kerja kosakata, rekaman (program audio), berpublikasi, berbagi dalam grup, membaca, berbicara.

Berdasarkan pengamatan, kegiatan prelistening belum dimaksimalkan. Padahal, dengan memaksimalkan kegiatan tersebut, mahasiswa secara otomatis membekali diri dengan pengetahuan pendahuluan yang akan dilengkapi atau dikonfirmasi dalam kegiatan menyimak di kelas. Dengan memaksimalkan kegiatan persiapan sebelum menyimak (prelistening) ini, mahasiswa diharapkan dapat merencanakan secara jelas langkah proses pembelajaran berikutnya. Demikian juga halnya dengan kegiatan postlistening. Berdasarkan pengamatan, kegiatan pascamenyimak (postlistening) juga baru sebatas pengumpulan laporan sebagai kegiatan final.

Kegiatan menyimak kuliah yang merupakan salah satu materi dalam mata kuliah Menyimak Komprehensi dan Kritis merupakan materi yang penting karena kegiatan ini menunjang keberhasilan pencapaian seorang mahasiswa dalam studinya di perguruan tinggi. Hal ini mengingat sebagian besar proses perkuliahan dilalui dengan kegiatan menyimak. Selain itu, kegiatan menyimak kuliah perlu mendapat perhatian karena merupakan salah satu faktor penting yang mempengaruhi keberhasilan seorang mahasiswa menempuh proses pembelajaran di perguruan tinggi. Hal lain yang mendukung hal tersebut adalah posisi mata kuliah tersebut yang berada di semester awal yang berarti membekali mahasiswa untuk menyiapkan strategi untuk sukses di perguruan tinggi.

Kegiatan perkuliahan merupakan kegiatan menyerap infomasi atau ilmu pengetahuan yang harus ditempuh oleh seorang mahasiswa perguruan tinggi. Materi perkuliahan biasanya disampaikan oleh dosen dengan berbagai gaya dan teknik yang diyakini mampu mengefektifkan perkuliahan. Kegiatan yang dominan ditempuh oleh mahasiswa di dalam kelas adalah kegiatan menyimak materi perkuliahan baik yang disampaikan oleh dosen maupun mahasiswa yang kebetulan harus presentasi.

Dalam kegiatan menyimak materi perkuliahan terdapat beberapa hal yang harus diperhatikan yaitu: (1) materi kuliah, dan (2) penyampaian materi (Pintamtyastirin, 1984: 63). Pada saat penyampaian materi kuliah, hal yang perlu diperhatikan adalah pokok bahasan dan subpokok bahasan yang biasanya disampaikan di awal perkuliahan. Adapun dalam hal penyampaian materi, yang perlu diperhatikan adalah pemakaian bahasa, uraian, dan tanya jawab.

Evaluasi pembelajaran menyimak kuliah mengikuti rambu-rambu teknik 5R (Record, Reduce, Recite, Reflect, and Review). Dalam teknik ini mahasiswa dituntut menuliskan halhal yang dipahami melalui kegiatan menyimak. Dalam kegiatan rekam (record) mahasiswa harus menuliskan kata/frasa kunci/ hal-hal penting yang mewakili pemahaman mahasiswa terhadap materi yang diserap melalui kegiatan kuliah. Adapun pada bagian ringkas (reduce) mahasiswa harus menuliskan kata/frasa kunci yang menggambarkan pokok bahasan, subpokok bahasan, dan inti materi. Pada bagian daras (recite) mahasiswa mengungkapkan kembali pemahanannya dengan cara menguraikan kembali materi kuliah dengan menggunakan kalimat sendiri. Bagian yang dapat mendukung pemahaman terhadap materi adalah bagian refleksi (reflect). Dalam bagian ini mahasiswa dituntut dapat menghubungkan pemahaman baru dengan pemahaman sebelumnya serta aplikasinya dalam kehidupan sehari-hari. Sebagai langkah terakhir adalah tinjau ulang (review) (Pauk, 1983:17).

Evaluasi atau penilaian menyimak berdasarkan langkah tersebut selanjutnya diberi poin dapat dilihat pada Tabel 1 .

Dalam perkembangannya, evaluasi keterampilan menyimak yang memperhatikan aspek verbal dan nonverbal terdapat banyak faktor lain yang cukup berpengaruh dalam pemahaman menyimak. Sebagai contoh adalah perkembangan penggunaan media termasuk di dalamnya media audio maupun audiovisual. Seperti dikatakan Buck (2001: 257) tes menyimak memang kompleks dan menantang, namun dengan kepedulian dan usaha, hal tersebut tetap dapat dilakukan. Pedoman penilaian di atas masih dapat diterapkan untuk materi dengan berbagai macam media karena yang dituntut dari mahasiswa bukan pemahaman verbal saja, melainkan juga pemahaman secara komprehensif. 
Tabel 1. Pedoman Penilaian Keterampilan Menyimak Kuliah

\begin{tabular}{|c|c|c|}
\hline $\mathbf{R}$ & Aspek-Aspek yang Dinilai & $\begin{array}{c}\text { Skor } \\
\text { maksimal }\end{array}$ \\
\hline $\begin{array}{c}1 \\
\text { (Record) }\end{array}$ & $\begin{array}{c}\text { Gagasan penting dalam materi kuliah (Pokok bahasan, } \\
\text { subpokok bahasan, penjelasan penting (2) } \\
\text { Bahasa (1) }\end{array}$ & 3 \\
\hline $\begin{array}{c}2 \\
\text { (Reduce) }\end{array}$ & Kata/frasa kunci (2) & 2 \\
\hline $\begin{array}{c}3 \\
\text { (Recite) }\end{array}$ & $\begin{array}{c}\text { Uraian runtut dan referensi lengkap }(1.5) \\
\text { Kalimat efektif }(0,5) \\
\text { Memberi penilaian terhadap pemakaian bahasa }(0,5)\end{array}$ & 25 \\
\hline $\begin{array}{c}4 \\
\text { (Reflect) }\end{array}$ & $\begin{array}{l}\text { Gagasan/Opini dengan alasan logis (1) } \\
\text { Analisis, sintesis, dan argumen, fakta (1) }\end{array}$ & 20 \\
\hline \multirow[t]{2}{*}{$\begin{array}{c}5 \\
\text { (Review) }\end{array}$} & Hal-hal tambahan (kata sulit dan penjelasannya) & 05 \\
\hline & Skor Total & 10 \\
\hline
\end{tabular}

\section{METODE PENELITIAN}

Penelitian ini merupakan penelitian deskriptif kualitatif dengan subjek mahasiswa semester dua angkatan 2013/2014 program studi PBSI FBS UNY yaitu kelas A dan G. Tempat penelitian ini adalah seluruh wilayah FBS yang digunakan sebagai tempat kuliah mahasiswa prodi Pendidikan Bahasa dan Sastra Indonesia, yang biasanya meliputi ruang kuliah di GK 1 dan C.15. Adapun waktu penelitian adalah pada September sampai Desember 2013. Teknik pengumpulan data dalam penelitian ini adalah teknik observasi perticipan (participant observer) Pengumpulan data dalam penelitian ini dilakukan oleh peneliti sendiri sebagai instrumen inti dengan bantuan instrumen lain berupa catatan lapangan, dan dokumentasi audio visual. Kredibilitas data dalam penelitian ini dicapai dengan trianggulasi.

\section{HASIL DAN PEMBAHASAN}

Pembelajaran menyimak komprehensi dapat didesain dalam bentuk kegiatan pramenyimak (prelistening) dan pascamenyimak (postlistening) (Goh, 2002).

\section{Kegiatan Pramenyimak (Pre-listening)}

a. Diskusi

Kegiatan diskusi yang dilakukan oleh mahasiswa idealnya adalah diskusi seputar topik materi perkuliahan yang akan dibahas oleh dosen. Akan tetapi, yang terjadi adalah justru diskusi tentang rencana strategi mereka agar ketika menyimak kuliah dengan dosen tertentu tidak mengalami kesulitan, sebagai contoh strategi mereka ketika akan kuliah dengan dosen yang uraiannya tanpa slide dan dengan menggunakan slide, strategi menghadapi dosen dengan tipe tuturan dan penjelasan yang memutar-mutar atau dosen yang penjelasannya simpel. Berikut ini vignett yang menggambarkan kegiatan diskusi menjelang menyimak kuliah.

Vignett. 1. Kegiatan Diskusi Sebelum menyimak materi kuliah

Kegiatan diskusi mahasiswa sebelum mengikuti kegiatan menyimak kuliah di kelas A diwarnai dengan beberapa dialog baik antara mahasiswa dengan mahasiswa atau mahasiswa dengan dosen menyimak. Sebagai antara contoh, M1 dan M2: "Eh bapaknya itu kalau bicara muter-muter ya? Terus susah dicari intinya". Jawab M2: "Ya lagian penjelasannya lompatlompat". Di sisi lain ada pertanyaan mahasiswa kepada dosen menyimak tentang cara menebak topik, "Bu bolehkah kita menebak judul topik, soalnya bapaknya tidak pakai slide dan begitu salam crita terus sampai waktu habis".

Di kelas lain yang menyimak materi kuliah yang berbeda, pertanyaan mahasiswa juga masih tentang strategi memahami materi. Sebagai contoh seorang mahasiswa M4: "Bu ba- 
gaimana cara mengatasi rasa kantuk karena capek dan materi agak sulit". Terdapat pertanyaan lain misalnya M5: "Bu kalau ada pertanyaan mahasiswa pada saat proses kuliah termasuk hal perlu dicatat atau tidak" ada pertanyaan lain, "Bagaimana kalau penjelasan dosen belum semua disampaikan padahal waktu habis dan tidak diulang di pertemuan berikutnya?

(Sumber catatan lapangan dan hasil wawancara)

Berdasarkan Vignett 1 yang tampak adalah diskusi tentang bagaimana cara agar sukses memahami materi kuiah melalui kegiatan menyimak.

b. Membuat pertanyaan tentang topik (question)

Sebelum kegiatan menyimak kuliah, beberapa mahasiswa mengaku menyiapkan beberapa pertanyaan yang berhubungan dengan materi perkuliahan. Hanya saja proses ini dilakukan sesaat setelah mengetahui topik yang akan dibahas dan setelah mahasiswa membaca sekilas materi yang akan dijelaskan oleh dosen. Pun demikian, menurut pengakuan mereka penyampaian pertanyaan sangat mempertimbangkan kondisi perkuliahan yang berlangsung dan bergantung pada dosen yang bersangkutan.

c. Membaca sekilas (skimming) bacaan yang terkait dengan topik.

Beberapa mahasiswa mengakui bahwa sebelum mengikuti kuliah mereka sempat membaca sekilas materi yang akan disampaikan dosen baik berdasarkan keinginan sendiri dan terrutama jika diminta atau diberi tugas oleh dosen.

\section{Kegiatan Pascamenyimak (Post-listening)}

a. Menulis esai singkat (short written texts) Pada kegiatan pascamenyimak (post listening) kuliah, mahasiswa membuat esai singkat berdasarkan pemahaman baru dari kegiatan menyimak yang baru saja dilakukan. Isi esai tersebut berisi gagasan atau opini mahasiswa dari hasil menghubungkan antara pengetahuan baru dari kegiatan menyimak kuliah dengan pengetahuan sebelumnya yang sudah mereka miliki.
Dalam teknik 5R, kegiatan tersebut termasuk dalam kegiatan refleksi (reflect) yaitu membuat refleksi dengan menghubungkan anatara materi yang baru saja diperoleh dengan pengetahuan sebelumnya yang sudah dimiliki. Dalam menulis esai ini mahasiswa juga diimbau untuk memperhatikan kebahasaan yang digunakan.

\section{b. Membuat ringkasan materi}

Kegiatan setelah menyimak yang lain adalah membuat ringkasan. Ringkasan tersebut berupa menuliskan pokok bahasan dan subpokok bahasan serta poin-poin penting yang berkaitan dengan materi perkuliahan yang disimak. Pembuatan ringkasan dilakukan di rumah setelah mahasiswa menuliskan hal-hal penting hasil menyimak kuliah di kelas.

Ringkasan materi yang ditulis oleh mahasiswa berupa penulisan pokok bahasan dan subpokok bahasan serta penjelasan tambahan yang berupa poin-poin penting berupa kata/ frasa saja. Penulisan ringkasan ini diletakkan di bagian kiri dan menyerupai kerangka karangan. Berikut ini contoh tampilan catatan yang dibuat oleh mahasiswa.

\begin{tabular}{|c|c|}
\hline $\begin{array}{c}\mathrm{R} 2 \\
\text { Reduce (recite) }\end{array}$ & $\begin{array}{c}\text { Rl } \\
\text { Rekam (record) }\end{array}$ \\
\hline Kata/frasa kunci & Hal-hal penting \\
\hline Pokok bahasan & yang terkait dengan \\
\hline Subpokok bahasan & materi \\
\hline- & (uraian ringkas dan \\
\hline - & $\begin{array}{l}\text { mengikuti } \\
\text { pemateri) }\end{array}$ \\
\hline
\end{tabular}

(Pauk, 1984)

Ringkasan materi ini dapat digunakan untuk mengecek ingatan dengan cara menutup/ menekuk bagian kanan kertas sehingga yang terlihat hanya poin-poin utama saja.

\section{c. Analisis kebahasaan (language work)}

Setelah mengikuti kegiatan menyimak kuliah, mahasiswa melakukan analisis kebahasaan terhadap penggunaan bahasa yang digunakan oleh pemateri. Hal ini berkaitan dengan pembiasaan mahasiswa berbahasa secara baik dan benar karena mereka akan menjadi guru bahasa Indonesia. Akan tetapi, sayangnya analisis 
ini tidak disampaikan secara tertulis seperti yang disarankan dalam teknik 5R. Analisis bahasa ini disampaikan secara lisan setelah menyimak materi kuliah seperti yang tampak dalam vignett berikut.

Vignett 2. Analisis pemakaian bahasa pemateri

Pemakaian bahasa dosen/pemateri dalam kegiatan kuliah menurut sebagian besar mahasiswa sudah sesuai kaidah formal dari segi kalimat. Akan tetapi, menurut beberapa mahasiswa lain, dari segi penggunaan kosakata terkadang terdapat beberapa kata yang menurut mereka sulit karena merupakan kosakata baru. Terkadang juga tampak logat yang bersifat kedaerahan masih muncul. Hal yang membuat mahaiswa sedikit sulit memahami adalah cara menjelaskan yang digunakan oleh dosen X (M1: "Bahasanya muter-muter dan lompat-lompat"). (M2: "Kadang bingung tapi ya kalau baca lagi bisa paham").

(Sumber: Catatan lapangan dan hasil wawancara)

Dari gambaran vignett 2, analisis penggunaan bahasa dosen tidak dilakukan secara detail. Mahasiswa hanya menyimpulkan secara global dan dengan pengetahuan kebahasaan yang minim. Hal ini sedikit dapat dipahami karena mahasiswa tersebut masih berada pada semester satu.

d. Menggunakan kosakata tertentu yang baru dipahami untuk mengungkapkan gagasan (vocabulary work) berdiskusi tentang materi yang sudah dipahami melalui kegiatan menyimak kuliah (group sharing)

Mahasiwa menguraikan kembali materi yang sudah mereka pahami melalui kegiatan menyimak dengan bahasa mereka sendiri. Dalam hal ini berarti mereka menggunakan kembali kata-kata atau istilah yang baru saja mereka pahami melalui kegiatan menyimak. Dengan menggunakan kata-kata tersebut untuk menguraikan gagasan berarti mahasiswa dapat memahami konsep baru yang mereka pelajari

Dalam teknik 5R, kegiatan tersebut termasuk dalam kegiatan R3 atau menulis ulang (recite). Untuk mengantisipasi kekurangpahaman mereka terhadap kosakata baru biasanya mereka melakukan seperti: bertanya pada dosen, melihat kamus, atau membaca referensi yang relefan.

e. Membaca bacaan yang relefan dengan materi (reading)

Kegiatan lain yang dilakukan oleh mahasiswa setelah menyimak adalah membaca referensi yang terkait dengan materi. Sebagai contoh dalam suatu kegiatan menyimak materi tentang agama, mahasiswa pada saat mencatat uraian dosen, mereka hanya menuliskan surat dalam Alquran sesuai dengan surat dan nomor ayat yang ditunjuk. Setelah sampai di rumah, yaitu pada saat mereka sampai pada proses mengungkapkan kembali, mahasiswa melengkapi catatan mereka dengan menuliskan ayat tersebut secara utuh beserta artinya. Untuk sampai pada kegiatan ini mahasiswa memerlukan bacaan yang relefan baik berupa Alquran beserta terjemahannya atau buku referensi yang relefan.

Selain itu, menurut mahasiswa terkadang untuk melengkapi keterangan dosen yang dirasa kurang atau ada poin yang tertinggal, mereka juga membaca bacaan relefan untuk melengkapi catatannya. Berdasarkan data tersebut, dapat dicermati bahwa secara kuantitas kegiatan pre-listening lebih sedikit dibandingkan dengan kegiatan postlistening. Selain itu, secara kualitas, berdasarkan data yang diperoleh yaitu dari catatan yang dibuat oleh mahasiswa dan berdasarkan wawancara, kegiatan pramenyimak pre dan pascamenyimak postlistening masih perlu dimaksimalkan. Sebagai catatan penting dari penerapan kegiatan tersebut, kegiatan postlistening dilakukan oleh mahasiswa dapat efektif hanya jika dikemas dalam sebuah rangkaian tugas. Sebagai perbandingan, kegiatan prelistening yang sifatnya hanya berupa imbauan, hanya dilakukan oleh beberapa mahsiswa dan sulit dikontrol secara maksimal

\section{PENUTUP}

Berdasarkan hasil dan pembahasan di atas, hasil penelitian ini dapat disimpulkan sebagai berikut. Kegiatan pramenyimak (prelistening) yang dilakukan sebelum menyimak kuliah(1) diskusi, (2) membuat pertanyaan tentang topik (question), dan (3) membaca sekilas (skimming) bacaan yang terkait dengan topik. 
Adapun kegiatan pascamenyimak (postlistening) yang dilakukan oleh mahasiswa adalah (1) menulis esai singkat (short written texts), (2) membuat ringkasan materi, (3) analisis kebahasaan (language work), (4) menggunakan kosakata tertentu yang baru dipahami untuk mengungkapkan gagasan (vocabulary work), (5) berdiskusi tentang materi yang sudah dipahami melalui kegiatan menyimak kuliah (group sharing), dan (6) membaca bacaan yang relefan dengan materi (reading).

Pelaksanaan kegiatan pramenyimak (prelistening) dan (postlistening) berdasarkan kuantitas maupun kualitasnya belum maksimal. Pelaksanaan kegiatan pascamenyimak (postlistening) dapat terlaksana secara efektif jika dikemas dalam sebuah rangkaian tugas. Jika tidak demikian, pelaksanaan hanya dilakukan oleh mahasiswa tertentu yang berminat dan mahasiswa lain bertindak semaunya sendiri.

\section{DAFTAR PUSTAKA}

Buck, Gary. 2001. Assessing Listening.Cambridge: Cambridge University Press.

Goh, Christine C.M.. 2002. Taeching Listening in The Language Classroom. Singapore: SEAMEO Regional Language Center.

Pauk, Walter. 1984. "Sistem pencatatan kuliah menurut Universitas Cornell" dalam Kemajuan studi. No. 3 Tahun 1984.

Pintamtiyastirin. 1983. Menyimak dan Pengajarannya. Yogyakarta: IKIP Yogyakarta.

Tarigan, Henry Guntur. 1985. Menyimak sebagai Suatu Keterampilan Berbahasa. Bandung: Angkasa. 